\title{
Gorontalo
}

Journal of Government and Political Studies

Volume 4 - NO. 1 - April 2021

P-ISSN: 2614-2120 E-ISSN: 2614-2104

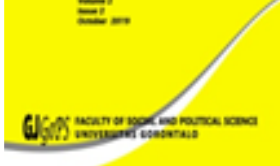

\section{Strategi Pemerintah Daerah Kabupaten Karawang dalam Peningkatan Produktivitas Program Usaha Peningkatan Pendapatan Keluarga Sejahtera}

\author{
Siti Habsyah Yuliani, \\ Hanny Purnamasari, \\ Ani Nurdiani Azizah \\ Universitas Singaperbangsa Karawang \\ J1. HS. Ronggo waluyo, Puseurjaya, \\ Kecamatan telukjambe Timur, \\ Kabupaten Karawang, Jawa Barat 41361 \\ 1610631180190@student.unsika.ac.id
}

Received: 23rd September 2020; Revised: 09th March 202 1;

Accepted: 18th March 2021

\begin{abstract}
The purpose of this research is to analyze local government strategies in increasing the productivity of the UPPKS program. The method used in qualitative descriptive research using the theory of $J$ Salusu Strategy in four dimensions, namely Identification, Development, Completion, Implementation and Evaluation with a qualitative descriptive approach. Data collection techniques were used through observation, interviews, documentation and literature study with employee informants of the Population Control and Family Planning Office of Karawang Regency. In this study, researchers used a descriptive research method with a qualitative approach carried out by literature and field studies. Field studies were carried out through observation and interviews The results showed that, the strategy of the Karawang Regency Government in increasing the productivity of the Prosperous Family Income Improvement Business Program (UPPKS) was less than optimal, it was seen through the identification phase where there were still constraints on the limited budget. The implementation and evaluation phases motivate the Dinas to continue to improve its services to the community in Increasing Program Productivity with all running programs.
\end{abstract}

Keywords: strategy; local government; increased productivity; UPPKS

Tujuan penelitian ini akan menganalisis strategi pemerintah daerah dalam peningkatan produktivitas program UPPKS. Metode yang digunakan dalam penelitian deskriptif kualitatif dengan menggunakan teori Strategi J Salusu dalam empat dimensi yaitu Identifikasi, Pengembangan, Penyelesaian, Implementasi dan Evaluasi dengan pendekatan deskriptif kualitatif. Teknik pengumpulan data digunakan melalui observasi, wawancara, dokumentasi dan studi pustaka dengan informan pegawai Dinas Pengendalian Penduduk dan Keluarga Berencana Kabupaten Karawang. Dalam penelitian ini peneliti menggunakan metode penelitian deskriptif dengan pendekatan secara kualitatif yang dilakukan dengan studi pustaka dan studi lapangan. Studi lapangan dilakukan melalui observasi dan wawancara. Hasil penelitian menunjukkan bahwa, Strategi Pemerintah Daerah Kabupaten Karawang dalam Peningkatan 
Produtivitas Program Usaha Peningkatan Pendapatan Keluarga Sejahtera (UPPKS) kurang optimal, hal tersebut dilihat melalui fase identifikasi yang mana masih ada kendala pada anggaran yang terbatas. fase implementasi dan evaluasi menjadikan motivasi agar Dinas terus memperbaiki pelayanannya terhadap masyarakat dalam Penigkatan Produktivitas Program dengan semua program yang berjalan.

Kata kunci: strategi; pemerintah daerah; peningkatan produktivitas; UPPKS

\section{PENDAHULUAN}

Manusia merupakan unit terkecil dalam keluarga, dimana manusia adalah mahkluk sosial yang tidak terlepas pada kehidupan sosial di masyarakat salah satunya dalam kehidupan ber-keluarga. Dalam keluarga, kesejahteraan merupakan persoalan yang sangat berpengaruh dalam kualitas keluarga. Kesejahteraan keluarga adalah kondisi dimana adanya beberapa kebutuhan yang harus terpenuhi sehari-hari oleh keluarga. kesulitan yang di alami tersebut pada keluarga dapat berakibat negatif serta dapat berpengaruh pada pertumbuhan dan stabilitas perekonomian suatu daerah.

Keluarga Pra-Sejahtera (KPS) adalah dimana kondisi suatu keluarga dalam taraf hidup yang rendah, khususnya dari segi ekonomi yang dialami oleh keluarga sehingga tidak dapat memenuhi kebutuhan dasar suatu keluarga seperti sandang, pangan, papan, pendidikan maupun kesehatan. Keberadaan Keluarga Pra-Sejahtera (KPS) pada suatu daerah merupakan masalah yang cukup penting untuk di tindak lanjuti, karena keluarga adalah inti dari masyarakat yang berperan dalam kemajuan pada pembangunan suatu daerah. Jika kondisi keluarga berada pada taraf hidup yang rendah maka daerah tersebut belum optimal dalam pembangunan daerahnya. Sementara, di kabupaten Karawang keberadaan Kepala Keluarga Pra-sejahtera jumlahnya masih cukup banyak yaitu sekitar 111.825, berdasarkan Badan Pusat Statistik Kabupaten Karawang. Oleh karena itu, pemerintah kabupaten Karawang membentuk kelompok Usaha Peningkatan Pendapatan Keluarga Sejahtera di daerah yang terdapat Kampung KB.

Menurut buku panduan Usaha Peningkatan Pendapatan Keluarga Sejahtera (UPPKS), Badan Kependudukan dan Keluarga Berencana Nasional (2015) bahwa : Program UPPKS merupakan wadah pembelajaran untuk mengenal usaha skala rumah tangga yang bertujuan meningkatkan kesejahteraan keluarga, khususnya KPS (Keluarga Pra-Sejahtera) dan KS I, artinya UPPKS berusaha mewujudkan keluraga kecil bahagia sejahtera. UPPKS merupakan program yang bersumber dari pemerintah pusat, Badan Kependudukan dan Keluarga Berencana Nasional (BKKBN) kepada pemerintah daerah yang ada di indonesia melalui Dinas Pengendalian Penduduk dan Keluarga Berencana. Dengan diterapkannya program tersebut di daerah kabupaten Karawang yaitu untuk mengatasi masalah ekonomi, sehingga dapat meminimalisir jumlah Keluarga Pra-Sejahtera yang ada di Kabupaten Karawang. Dengan masih banyaknya jumlah Keluarga Pra-Sejahtera di kabupaten Karawang, hal tersebut menunjukan bahwa masih terdapatnya masalah pada produktivitas program UPPKS tersebut.

Dimana, tingkat produktivitas program yang ada pada program UPPKS sangat berpengaruh terhadap keberhasilan suatu program yang diterapkan pada Keluarga Pra-Sejahtera sebagai sasarannya. Masalah yang ada pada produktivitas program ini yaitu, keahlian yang dimiliki para anggota kelompok UPPKS di kabupaten Karawang masih belum terampil, berdasarkan hasil Pra- 
Penelitian di Dinas Pengendalian Penduduk dan Keluarga Sejahtera menurut bapak H. Warja Sudrajat S.E selaku kepala seksi pendayagunaan PKB/PLKB/IMP pada tanggal 02 Maret 2020 mengatakan : skill (keahlian) para anggota kelompok UPPKS untuk meningkatkan kualitas produk masih belum terampil, dan tidak ulet. Misalnya diminta untuk mengumpulkan persyaratan perijinan produk mereka tidak mengumpulkan sehingga produk yang di hasilkan hanya itu saja atau tidak adanya peningkatan dari segi kualitas dan jenisnya. Selain itu, masalah yang ada dalam produktivitas program ini yaitu adanya tindakan ditiadakannya bantuan pinjaman dana bergulir kepada kelompok UPPKS sejak tahun 2018 kemarin, karena sudah tidak ada lagi anggaran untuk bantuan tersebut dari pemerintah pusat. bantuan pinjaman Dana Bergulir ini merupakan akses modal para kelompok UPPKS guna mendukung kegiatan produksi kelompok UPPKS agar kegiatan ini berjalan dengan sebagaiman mestinya, dan diganti dengan adanya bantuan Alat Teknologi Tepat Guna (ATTG) kepada kelompok UPPKS di Kabupaten Karawang.

Kurangnya akses modal merupakan masalah serius yang terjadi pada faktor pendukung produktivitas pogram UPPKS. Karena pada dasarnya jika akses modal yang dimiliki oleh kelompok UPPKS memadai tentu dapat mendukung berlangsungnya kegiatan UPPKS seperti, dapat menghasilkan produk yang bagus dan bervariasi jenisnya. Selain itu, banyak kelompok UPPKS yang aktif dalam kegiatan produksi. Sehingga dapat meningkatkan pendapatan keluarga para anggota kelompok UPPKS itu sendiri. Modal dalam kegiatan tersebut merupakan faktor yang sangat berpengaruh untuk kelangsungan berjalannya kegiatan. Jika tidak adanya akses modal dapat mengakibatkan kegiatan tersebut akan terhenti, dan para anggota kelompok UPPKS tidak bisa menghasilkan suatu produk. Maka program tersebut berjalan tidak sesuai dengan tujuannya yaitu untuk meningkatkan pendapatan keluarga dalam mencapai kesejahteraan keluarga.

Adanya bantuan ATTG kepada kelompok UPPKS merupakan strategi Dinas Pengendalian Penduduk dan Keluarga Berencana Kabupaten Karawang, dalam mengatasi bentuk bantuan pinjaman dana bergulir yang telah ditiadakan sebelumnya. Bantuan ATTG ini diberikan kepada setiap kelompok UPPKS mendapatkan sekitar 1 (satu) paket alat guna menunjang kegiatan produksi pada kelompok UPPKS tersebut. Selain itu, Alat Teknologi Tepat Guna di sesuaikan dengan kebutuhan kelompok UPPKS masing-masing. Akantetapi, keberadaan Alat Teknologi Tepat Guna) pada program ini dirasa belum optimal dalam meningkatkan produktivitas dari program UPPKS di Kabupaten Karawang, karena pemberian bantuan dengan ATTG belum merata akibat dari ketersediaan alat bantuan tersebut masih terbatas. Jumlah kelompok UPPKS di kabupaten Karawang sebanyak 246 kelompok pada tahun 2020. Artinya jumlah kelompok UPPKS yang ada di kabupaten Karawang cukup banyak. Sementara, data jumlah kelompok UPPKS yang menerima bantuan ATTG Pada tahun 2018 Dinas Pengendalian Penduduk dan Keluarga Berencana Kabupaten Karawang telah menyalurkan bantuan ATTG sebanyak 4 (Empat) paket untuk 4 (Empat) kelompok UPPKS yang ada di empat Kecamatan; Batujaya, Cilamaya Wetan, Telukjambe Timur, Rengasdengklok. Sedangkan, pada tahun 2019 dinas telah menyalurkan bantuan sebanyak 6 (Enam) paket untuk diberikan kepada 6 (Enam) kelompok UPPKS di enam kecamatan; Cilebar, Kotabaru, Banyusari, Tegalwaru, Cibuaya, dan Pedes Kabupaten Karawang. Data-data tersebut 
membuktikan bahwa, pada setiap tahunnya ketersediaan jumlah bantuan ATTG masih sangat kurang sedangkan permintaan pemenuhan ATTG lebih dari itu. Dalam hal ini tentu adanya kesenjangan antara jumlah permintaan ATTG dengan ketersediaan ATTG. Sehingga kelompok UPPKS yang ada di kabupaten Karawang tidak dapat merasakan fasilitas yang diberikan pemerintah secara merata.

Oleh karena itu pemberian ATTG dirasa sangat penting untuk kemajuan kegiatan program UPPKS di Dinas Pengendalian Penduduk dan Keluarga Berencana Kabupaten Karawang. Namun tidak meratanya pemberian ATTG kepada kelompok UPPKS di Kabupaten Karawang karena kurangnya anggaran dana Dinas Pengendalian Penduduk dan Keluarga Berencana Kabupaten Karawang sehingga belum maksimal.

Sebelumnya telah dilakukan penelitian mengenai Program UPPKS yaitu (Simon JV Silaen, 2016), (Khoirul Imrah, 2018), (Syafiq Abriansyah, 2019) menunjukkan bahwa program UPPKS dilaksanakan di Medan, Lampung Barat, Kepahiang dengan hasil yang berbeda-beda. Dari 3 penelitian terdahulu tersebut sebagian berhasil dan sebagian belum seperti masih rendahnya pasrtisipasi masyarakat dalam pelaksanaan program tersebut. Sosialisasi program yang belum maksimal dan dalam peningkatan kualitas produksi harus ditingkatkan lagi oleh pemilik atau pengelola usaha ekonomi kreatif sehingga program UPPKS dapat berjalan dengan maksimal. Terdapat perbedaan pada penelitian ini yaitu penelitian ini dengan penelitian-penelitian sebelumnya, penelitian ini fokus pada strategi Dinas Pengendalian Penduduk dan Keluarga Berencana dalam peningkatan produktivitas program UPPKS melaui bantuan ATTG, lokus penelitian ini dilakukan di daerah Kabupaten Karawang. Selanjutnya yang menjadi acuan dalam menganalisis penelitian ini adalah teori strategi atau 4 fase yang perlu ditempuh dalam membuat keputusan menurut $\mathrm{J}$ salusu yaitu : fase identifikasi, fase pengembangan, fase penyelesaian, fase implementasi dan evalusi (J.Salusu, 2015).

Dalam rangka meningkatkan potensi masyarakat dalam hal kesejahteraan yang bertujuan untuk mengatasi masalah kesejahteraan khususnya mengurangi jumlah Keluarga Pra-Sejahtera (KPS) yang ada di Kabupaten Karawang secara optimal. Oleh karena itu berdasarkan Peraturan Daerah Kabupaten Karawang Nomor 6 Tahun 2018 Tentang Penyelenggaraan Pembangunan Ketahanan Keluarga, peningkatan akses dan peluang terhadap penerimaan informasi dan sumber daya ekonomi melalui usaha mikro keluarga menjadi salah satu cara dalam menangani kesejahteraan keluarga dalam pelaksanaan program UPPKS. Program UPPKS merupakan wadah untuk masyarakat dalam berwirausaha sehingga masyarakat dapat mandiri dan kreatif dalam meingkatkan perekonomiannya.

\section{METODE PENELITIAN}

Metode yang digunakan oleh peneliti adalah pendekatan kualitatif dengan metode deskriptif yaitu dimana peneliti memberikan penjelasan dari hasil pengamatan dan tujuannya untuk memperjelas suatu teori, sehingga menghasilkan informasi mengenai keadaan sebenarnya berupa kata-kata lisan maupun tertulis, dan tingkah laku yang diamati dari orang-orang yang diteliti. Dimana terlihat fakta-fakta yang ada dan sebagaimana mestinya. Teknik Analisis Data di dalam penelitian kualitatif telah dilakukan sejak sebelum 
peneliti turun kelapangan dan setelah selesai dari lapangan. Untuk menganalisis data yang telah dikumpulkan, teknik analisa data adalah analisa deskriptif, dimana melalui teknik ini akan digambarkan seluruh data yang diperoleh dengan menerapkan prosedur.

Segala bentuk permasalahan dalam peningkatan produktivitas program Usaha Peningkatan Pendapatan Keluarga Sejahtera (UPPKS) di Kabupaten Karawang akan di analisis menggunakan teori pengamblan keputusan Stratejik dari J. Salusu (2015) yang terdapat 4 (empat) fase yaitu identifikasi, pengembangan, penyelesaian, implementasi dan evaluasi. Adapun teknik pengumpulan datanya dilakukan dengan 2 (dua) teknik yaitu : Melalui studi pustaka peneliti memperoleh data dan informasi dari buku-buku, dokumendokumen, jurnal dan literatur lainnya yang berkaitan dengan strategi Pemerintah daerah Kabupaten Karawang dalam peningkatan produktivitas program UPPKS. Melalui studi lapangan ini dibagi menjadi 2 (dua) cara yaitu melalui observasi dan wawancara. Penelitimelakukan observasi dengan mengamati segala bentuk kegiatan para pelaksana program UPPKS dan kelompok UPPKS yang menerima bantuan ATTG di Kabupaten Karawang. Sedangkan untuk wawancara dilakukan dengan para pegawai Dinas Pengendalian Penduduk dan Keluarga Berencana Kabupaten Karawang di Bidang Pembangunan Ketahanan Keluarga seperti Kepala Bidang Pembangunan Ketahanan Keluarga, Kepala Seksi Pemberdayaan Ekonomi Keluarga, Kepala Seksi Pendayagunaan PKB/PLKB/IMP, Kelompok UPPKS Kecamatan Rengasengklok, Kelompok UPPKS Kecamatan Pedes, Kelompok UPPKS Kecamatan Batujaya, Kelompok UPPKS Kecamatan Cilebar, Kelompok UPPKS Cibuaya di Kabupaten Karawang yang menerima bantuan ATTG.

\section{HASIL DAN PEMBAHASAN}

Dalam rangka meningkatkan potensi masyarakat dalam hal kesejahteraan yang bertujuan untuk mengatasi masalah kesejahteraan khususnya mengurangi jumlah Keluarga Pra-Sejahtera (KPS) yang ada di Kabupaten Karawang secara optimal. Oleh karena itu berdasarkan Peraturan Daerah Kabupaten Karawang Nomor 6 Tahun 2018 Tentang Penyelenggaraan Pembangunan Ketahanan Keluarga, peningkatan akses dan peluang terhadap penerimaan informasi dan sumber daya ekonomi melalui usaha mikro keluarga menjadi salah satu cara dalam menangani kesejahteraan keluarga dalam pelaksanaan program UPPKS. Program UPPKS merupakan wadah untuk masyarakat dalam berwirausaha sehingga masyarakat dapat mandiri dan kreatif dalam meingkatkan perekonomiannya.

Untuk menganalisa seberapa optimal strategi Pemerintah Derah Kabupaten Karawang dalam peningkatan produktivitas program tersebut, maka peneliti menggunakan teori pengambilan keputusan stratejik dari J. Salusu (2015) yang difokuskan pada 4 (empat) fase yaitu: Fase Identifikasi, Fase Pengembangan, Fase Penyelesaian serta Fase Implementasi dan Evaluasi.

\subsection{Fase identifikasi}

Fase mencakup beberapa hal penting, yaitu seseorang harus memiliki kesadaran akan perlunya keputusan. Ia juga perlu menyadari perlunya suatu proses yang ditempuh untuk tiba pada suatu keputusan yang baik, pada intinya langkah-langkah penting dalam identifikasi yaitu evaluasi terhadap kinerja 
organisasi sekarang, evaluasi tujuan, sasaran organisasi dan perumusan masalah, serta perancangan strategi yang baik. Perancangan strategi yang baik dan berhasil adalah tercapainya sasaran dan tujuan organisasi dengan baik, dimana sasaran dan tujuan ini disesuaikan dengan masalah yang terjadi pada masyarakat itu, barulah diadakan rapat untuk merancang strategi dan akhirnya memutuskan strategi yang merupakan hasil dari rapat tersebut.

Dari identifikasi strategi Dinas Pengendalian Penduduk dan Keluarga Berencana Kabupaten Karawang dalam peningkatan produktivitas program, permasalahan yang dihadapi Pemerintah Kabupaten Karawang adalah dalam mendongkrak ekonomi masyarakat/keluarga dengan keadaan keahlian yang dimiliki oleh masyarakatnya yang belum terampil serta masih kurangnya akses modal, dan penyaluran bantuan Alat Teknologi Tepat Guna yang tidak sebanding dengan permintaan kebutuhan suatu alat dalam menunjang kegiatan produksi. Dalam mengatasi hal tersebut Dinas Pengendalian Penduduk dan Keluarga Berencana Kabupaten Karawang berpendapat hal tersebut dikarenakan kurangnya kesadaran masyarakat dalam berwirausaha atau belum memiliki jiwa interpreneur, serta kurangnya dukungan dari Pemerintah Desa dalam pemberdayaan potensi yang ada pada daerahnya masing-masing. Seharusnya adanya kerjasama antara pemerintah daerah dengan pemerintah desa dalam mendongkrak ekonomi masyarakat. Hal tersebut disampaikan langsung oleh Bapak Drs. Yudha Wisnu selaku Kepala Bidang Pembangunan Ketahanan Keluarga Dinas Pengendalian Penduduk dan Keluarga Berencana. selain itu memberikan fasilitas berupa bantuan ATTG pada kelompok UPPKS guna menunjang kegiatan produksi. Akantetapi pemberian bantuan ATTG tersebut hanya dapat terealisasikan kepada beberapa kelompok saja. Dimana bantuan ATTG diberikan kepada kelompok UPPKS yang memiliki kriteria seperti, kelompoknya yang aktif, memiliki produk unggulan, serta terbentuknya kelompok UPPKS tersebut jelas keberadaannya, dibuktikan dengan adanya Surat Keputusan yang diterbitkan oleh Desa secara legal.

\subsection{Fase Pengembangan}

Pengembangan merupakan fase mengenai faktor-faktor apa saja yang berpengaruh dalam lingkungan internal kemudian memilih faktor-faktor stratejik berupa kekuatan dan kelemahan organisasi. Faktor-faktor apa saja yang berpengaruh dalam lingkungan eksternal dan kemudian memilih faktorfaktor stratejik berupa peluang dan ancaman-ancaman atau tantangan, dengan kata lain menganalisis SWOT (J.Salusu, 2015:281).

Dinas Pengendalian Penduduk dan Keluarga Berencana Kabupaten Karawang mengembangkan strategi dengan memanfaatkan Alat Teknologi Tepat Guna Sebagai media pendukung kegiatan produksi pada pelaksanaan program sudah dilakukan secara maksimal, hal tersebut dibuktikan dengan terbentuknya program UPPKS dimana untuk peningkatan produktivitas programnya dilakukan dengan memberikan bantuan ATTG kepada kelompok UPPKS yang memiliki potensi dan membutuhkan bantuan dalam meningkatkan usahanya. Sehingga program tersebut dapat berjalan dengan sebagaimana mestinya. Kemudian konsistensi Pemerintah dalam mensosialisasikan dan monitoring mengenai program UPPKS ini di berbagai kesempatan terutama pada kegiatan kunjungan ke kampung $\mathrm{KB}$ dan rapat secara rutin di awal bulan yang 
dihadiri para anggota kelompok UPPKS di Dinas Pengendalian Penduduk dan Keluarga Berencana Kabupaten Karawang.

Namun kendala mengenai pelaksanaan program UPPKS melalui bantuan ATTG ini dikarenakan membutuhkan anggaran yang cukup dalam pemenuhan ATTG secara merata. Selain itu membutuhkan usaha yang lebih serius dalam menumbuhkan jiwa berwirausaha para anggota kelompok UPPKS untuk menjalankan program UPPKS sebagai penghasil usaha kreatif di masyarakat, sehinggga dapat meningkatkan pendapatan masyarakat setempat.Berdasarkan wawancara di atas, peneliti menganalisis bahwa dalam Strategi pengembangan yang dilakukan oleh Dinas Pengendalian Penduduk dan Keluarga Berencana Kabupaten Karawang sejauh ini sudah dilaksanakan secara maksimal, secara konsisten melakukan sosialisasi, monitoring, membina, dan memfasilitasi kepada kelompok UPPKS yang ada di Kabupaten Karawang melaui mengadakan pertemuan di berbagai kesempatan di kantor DPPKB maupun di kantor UPT PPKB di setiap Kecamatan. Namun masih ada beberapa kelompok UPPKS kurang aktif dalam pelaksanaan program, intinya masih ada beberapa kelompok UPPKS yang memiliki jiwa berwirausahanya masih kurang dan belum siap untuk memajukan program UPPKS yang ada di Kabupaten Karawang.

\subsection{Fase Penyelesaian}

Penyelesaian Strategi meliputi peninjauan ulang tujuan tujuan dan sasaran jika dianggap perlu, perumusan alternatif-alternatif stratejik, penetapan alternatif terpilih berdasar prioritas dan pengesahan atas alternatif terpilih. Alternatif terpilih ini sudah disahkan menjadi keputusan stratejik. Dinas Pengendalian Penduduk dan Keluarga Berencana Kabupaten Karawang dalam penyelesaian strateginya mengenai peningkatan produktivitas program UPPKS melalui ATTG dengan fokus dan menindak lanjuti para kelompok UPPKS yang ada dengan cara diberikan arahan dan kemudian diberikan pelatihan oleh yang ahli di bidang usaha kecil menengah agar dapat meningkatkan kualitas para kelompok UPPKS dari segi permodalan, pemasaran, dan dalam pemanfaat ATTG.

Selanjutnya untuk meningkatkan jiwa berwirausaha para kelompok UPPKS di Kabupaten Karawang, pemerintah memberikan penghargaan kepada kelompok UPPKS yang memiliki kualitas terbaik dibandingkan kelompok UPPKS yang lain. Namun dalam menangani ketersediaan ATTG pemerintah masih berusaha memenuhi semua permintaan alat dengan cara mengutamakan kelompok UPPKS yang benar-benar membutuhkan dan memiliki potensi dalam usahanya, walaupun belum bisa memenuhi permintaan bantuan ATTG secara keseluruhan karena disesuaikan dengan anggaran yang ada pada setiap tahunnya.

Berdasarkan hasil wawancara dengan para informan penelitian diatas, peneliti melihat bahwa penyelesaian strategi Dinas Pengendalian Penduduk dan Keluarga Berencana Kabupaten Karawang dalam peningkatan produktivitas program melalui Alat Teknologi Tepat Guna sudah menjalankan tugasnya dengan maksimal dimana adanya upaya dalam mengatasi permasalahan yang ada pada pelaksanaan program UPPKS dengan terus memberikan pembinaan dalam mewujudkan kelompok UPPKS yang berkualitas dari segi SDM, produk, pemasaran dan mempermudah akses modal dengan merencanakan adanya kerjasama melalui perbankan. 
Selain itu, pemberian penghargaan tersebut merupakan suatu bentuk apresiasi dari pemerintah untuk para kelompok UPPKS yang unggul sehingga dapat memacu semangat dan dapat meningkatkan jiwa berwirausaha para kelompok UPPKS di Kabupaten Karawang. Namun masih sebagian kelompok UPPKS yang sudah mendapatkan bantuan ATTG tersebut di Kabupaten Karawang, yang mana kelompok UPPKS yang memanfaatkan ATTG sebagai faktor pendukung dalam proses produksinya hanya beberapa saja tidak pada semua kelompok UPPKS di Kabupaten Karawang.

\subsection{Fase implementasi dan evaluasi}

Strategi merupakan bagian terpenting dalam proses manajemen strategis. Fase implementasi dan evaluasi dilihat sebagai bagian integral dari proses pengambilan keputusan stratejik dengan pertimbangan bahwa keputusan stratejik baru mempunyai arti bagi organisasi apabila dilaksanakan dengan baik. Dinas Pengendalian Penduduk dan Keluarga Berencana Kabupaten Karawang dalam implementasi dan evaluasi strateginya sudah melakukan langkah yang baik dengan memfasilitasi kelompok UPPKS dengan memberikan bantuan ATTG sebagai penunjang kegiatan produksi dalam menjalankan program UPPKS. hal tersebut tentunya untuk mempermudah para anggota kelompok UPPKS dalam menghasilkan suatu produk yang memiliki nilai ekonomi yang tinggi sehingga dijadikan sumber pendapatan masyarakat setempat.

Dalam pemberian ATTG dari Dinas Pengendalian Penduduk dan Keluarga Berencana Kabupaten Karawang kepada para kelompok UPPKS tersebut tidak diberikan dengan cara begitu saja. Melainkan dengan adanya kriteria atau persyaratan yang harus dipenuhi oleh kelompok UPPKS yang akan menerima bantuan ATTG. Kriteria dalam pemberian ATTG yang diberikan pada kelompok UPPKS yaitu : 1) keberadaan kelompok UPPKS jelas dengan adanya Surat Keputusan yang di terbitkan oleh Kepala Desa setempat, 2) kelompok UPPKS aktif minimal sudah terbentuk selama 1 tahun, 3) memiliki potensi yang baik, 4) adanya pengajuan proposal ke instansi terkait terlebih dahulu. Namun sampai saat ini kelompok UPPKS KS Campernik tidak mendapatkan bantuan ATTG dari Dinas Pengendalian Penduduk dan Keluarga Berencana Kabupaten Karawang. Sedangkan kelompok UPPKS kami yang sudah jelas keberadaann sejak dulu mewakili kelompok UPPKS di Kecamatan Pedes dan sudah memiliki SK hal tersebut menunjukan bahwa kelompok UPPKS kami sesuai dengan kriteria yang ditentukan oleh DPPKB tapi tidak mendapatkan bantuan alat, melainkan yang mendapatkan bantuan ATTG tersebut yaitu salah satu kelompok UPPKS yang belum lama berdiri dan belum memiliki Surat Keputusan (SK) dari Desa Kertaraharja Kecamatan Pedes. Jadi kami dalam mengolah produk berupa minuman jahe merah instan dan kunyit instans masih menggunakan metode tradisional yaitu dengan parutan tangan untuk menghancurkan bahan baku seperti jahe merah dan kunyit hal tersebut disampaikan oleh Ibu Siti Rokayah selaku ketua kelompok UPPKS KS Campernik di Kecamatan Pedes.

Berikut merupakan berita acara data penerima bantuan ATTG kepada Kelompok UPPKS di Kabupaten Karawang yang dibuat oleh Dinas Pengendalian Penduduk dan Keluarga Berencana Kabupaten Karawang yang tidak sesuai dengan mekanisme pemberian bantuan ATTG oleh dinas : 


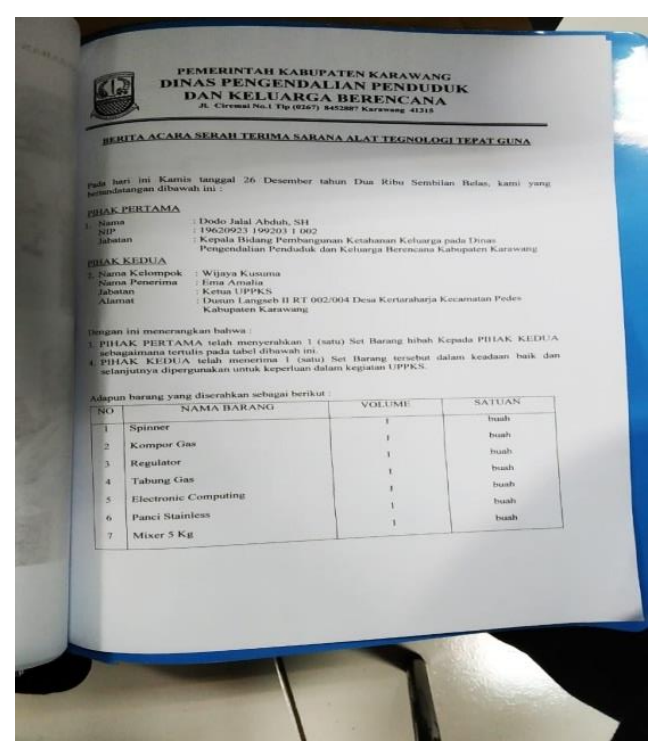

Gambar 1. Surat Berita Acara Serah Terima Alat Teknologi Tepat Guna (ATTG)

Pada gambar tersebut merupakan sebuah surat berita acara yang berisikan alat-alat apa saja yang diterima oleh kelompok UPPKS yang telah menerima bantuan dari DPPKB Kabupaten Karawang. Karena pada setiap kelompok UPPKS alat yang di butuhkan sebagai penunjang kegiatan produksi untuk menhasilkan suatu produk berbeda-beda. Selain itu, tidak hanya data alat apa saja yang diberikan kepada kelompok UPPKS tersebut, ada juga berupa data nama kelompok UPPKS, alamat, dan nama ketua kelompok yang tetera pada berita acara tersebut sebagai bukti bahwa bantuan ATTG sudah di salurkan. Pada gambar di atas diberitahukan bahwa kelompok UPPKS yg menerima bantuan yaitu kelompok Wijaya Kusuma yang diketuai oleh ibu Ema Amalia di Desa Kertaraharja Kecamatan Pedes Kabupaten Karawang. Alat Teknologi Tepat Guna ATTG yang diterima oleh kelompok UPPKS Wijaya Kusuma yaitu spinner 1 buah, kompor gas 1 buah, tabung gas 1 buah, electronic computing 1 buah, panci stainless 1 buah, dan mixer berat $5 \mathrm{~kg} 1$ buah. Sedangkan, kelompok UPPKS Wijaya Kusuma tersebut belum memiliki SK (Surat Keputusan) dari desa setempat. Dimana hal tersebut membuktikan bahwa tidak sesuai dengan mekanisme pemberian ATTG yang telah ditetapkan sebelumnya. Di kecamatan Pedes kelompok UPPKS yang sudah memiliki SK dan telah diakui keberadaannya yaitu KS Campeurnik yang diketuai oleh ibu Siti Rokayah. Ternyata Kelompok UPPKS tersebut tidak menrima bantuan ATTG dari DPPKB Kabupaten Karawang, hal tersebut membuktikan bahwa adanya ketidakseuaian antara data di berita acara dengan keadaan sebenarnya di lapangan.

\section{PENUTUP}

Pada fase identifikasi dapat di analisis bahwa kinerja Dinas Pengendalian Penduduk dan Keluarga Berencana Kabupaten Karawang sudah cukup baik, dimana mereka sudah mejalankan tugas sesuai dengan tugas dan fungsinya masing-masing walaupun masih terdapat kendala dari anggaran instansi yang terbatas kepada kelompok UPPKS. Masih perlu diadakannya perancangan strategi yang lebih baik dan kerjasamanya dengan pihak yang berwenang dalam 
menunjang kegiatan ekonomi kreatif masyarakat lebih di perhatikan lagi, sehingga bisa mencapai semua sasaran dan tujuan secara optimal.

Fase implementasi dan evaluasi strategi Dinas Pengendalian Penduduk dan Keluarga Berencana Kabupaten Karawang dalam peningkatan produktivitas Program UPPKS melalui bantuan ATTG diimplementasikan belum optimal, dapat dilihat bahwa dalam pemberian ATTG yang tidak tepat sasaran, kurangnya pemberian akses pemasaran terhadap kelompok UPPKS dari Dinas, kurangnya perluasan pemasaran produk dari kelompok UPPKS, serta evaluasi pencapaian pelaksanaan Program UPPKS ini belum tercapai karena terdapatnya banyak hambatan seperti tempat pemasaran yang diperuntukan para kelompok UPPKS berjualan sudah tidak beroperasi, masih ada kelompok UPPKS yang tidak aktif lagi produksi setelah menerima bantuan ATTG. hal tersebut menunjukkan tidak sesuainya dengan tujuan memberikan bantuan alat kepada kelompok UPPKS.

Atas kondisi tersebut peneliti menyampaikan beberapa rekomendasi dalam pelaksanaan program Usaha Peningkatan Pendapatan Keluarga Sejahtera (UPPKS), yaitu:

1) Menjalin kerajsama lintas sektor agar pemerintah desa lebih memperhatikan masyarakatnyan dari segi ekonomi usaha kelompok UPPKS yang ada di wilayahnya, serta menjalin kerjasama modal usaha desa dengan kelompok UPPKS sehingga dapat meningkatkan anggaran untuk produktivitas produk UPPKS di Kabupaten Karawang;

2) Perlu ada perbaikan komunikasi di birokrasi. Komunikasi yang dimaksud adalah antara pegawai Dinas Pengendalian Penduduk dan Keluarga Berencana, para pegawai di UPT tiap Kecamatan dengan para kelompok UPPKS. serta Dinas Pengendalian Penduduk dan Keluarga Berencana Kabupaten Karawang harus terus melalukan evaluasi mengenai program yang telah berjalan teruntama dengan adanya bantaun Alat Teknologi Tepat Guna (ATTG) ini, karena sangat di sayangkan jika dalam pemanfaatan alat bantuan tersebut tidak berjalan sesuai dengan fungsinya dengan tidak di iringi oleh adanya pengecekan secara berkala.

\section{DAFTAR PUSTAKA}

Ahmadi, Abu. 2002. Psikologi Sosial. Jakarta: Rineka Cipta

Arsyad, Umar. 2004. Pengetahuan Sosial. Jakarta: Erlangga

Basu Swastha, Ibnu Sukotjo. 1995.Pengantar Bisnis Modern.

Yogyakarta : Liberty

Cresswell, J. W. (2013). Research Desain Pendekatan Metode Kualitatif, Kuantitatif, dan Campuran. Yogyakarta: Pustaka Pelajar.

Fahmi, Irham. 2016. Pengantar Manajemen Sumber Daya Manusia Konsep Dan Kinerja. Jakarta: Mitra Wacana Media.

Fred R. David. 2011. Strategic Management (Managemen strategis). Jakarta: Salemba Empat.

Fred R. David. 2014. Analisis SWOT: Teknik Membedah Kasus Bisnis. Jakarta: Gramedia Pustaka Utama.

Hasan Irmayanti, Hasan. 2011. Manajemen Operasional Perspektif Integrative. UIN MALIKI PRESS (anggota IKAPI).

Herjanto, E. 2007. Manajemen Operasi. Jakarta: Grasindo.

Longman, Pearson. 2009. Dictionary of Contemporary English Fifth Edition (LDOCE5). ISBN-13: 978-1408215333. 
Panduan UPPKS Badan Kependudukan dan Keluarga Berencana Nasional 2015.

Peter Salim, Yeni Salim. 1995. Kamus Bahasa Indonesia Kontemporer. Jakarta : Modern Press.

Sinungan, Muchdarsyah. 2009. Produktivitas: Apa dan Bagaiamana. Jakarta: Bumi Aksara.

Sugiyono. 2012. Metode Penelitian Kuantitatif, kualitatif dan R\&D. Bandung : Alfabeta.

Sugiyono. 2018. Metode Penelitian Kuantitatif, kualitatif dan R\&D. Bandung : Alfabeta.

Sumardi, Woekirno. 1979. Faktor-FaktorProduktivitas Karyawan. Jakarta: Gramedia.

Syarif, Rusli. 1991. Produktivitas. Jakarta: Depdikbu.

Tim penyusun kamus besar bahasa indonesia. 1991. Kamus Besar Bahasa Indonesia. Jakarta: Balai Pustaka.

\section{Skripsi}

Imrah, khoirul. 2018. "Pemberdayaan Ekonomi Keluarga Melalui Program Usaha Peningkatan Pendapatan Keluarga Sejahtera (UPPKS) Di Pekon Wates Kecamatan Balik Bukit Kabupaten Lampung Barat”. Fakultas Dakwah Dan Ilmu Komunikasi. Universitas Islam Negeri Raden Intan lampung.

Silaen JV, Simon. 2016. "Penerapan Prinsip-Prinsip Community Development Dalam Pelaksanaan Program Usaha Peningkatan Pendapatan Keluarga Sejahtera Di Kecamatan Medan Helvetia Kota Medan”. Fakultas Ilmu Sosial Dan Ilmu Politik. Universitas Sumatera Utara. Medan.

Abriyansah, Syafiq. 2019. "Upaya Peningkatan Kualitas Home Industry Perspektif Produksi Dalam Islam (Studi Di Uppks Mawar Putih Kecamatan Kabawetan Kabupaten Kepahiang)". Fakultas Ekonomi Dan Bisnis Islam. Institut Agama Islam Negeri (Iain) Bengkulu. Bengkulu.

\section{Dokumen Lembaga}

Badan Pusat Statistik Kabupaten Karawang. 2018. Kabuapten Karawang dalam Angka 2018. ISSN: 0215.4307.

Badan Kependudukan dan Keluarga Berencana Nasional. 2020. Kelompok Kegiatan Ekonomi Keluarga Yang Mengakses Modal.

Dinas Pengendalian Penduduk dan Keluarga Berencana kabupaten Karawang. 2018. Berita Acara Serah Terima Sarana Alat Teknologi Tepat Guna.

Rencana Strategis (RENSTRA) Dinas Pengendalian Penduduk dan Keluarga

\section{Website} Berencana Kabupaten Karawang Tahun 2016-2021

BKKBN. 2011. Batasan dan Pengertian MDK [Online]

Tersedia di

http://aplikasi.bkkbn.go.id/mdk/BatasanMDK.aspx

Pemerintah Provinsi Jawa Barat. 2017. Kabupaten Karawang Profil Daerah [Online]

Tersedia di https://jabarprov.go.id/index.php/pages/id/1055 (Diakses pada tanggal 25 Juli 2020)

\section{Peraturan Perundang-Undangan}

Peraturan Bupati Karawang Nomor 37 Tahun 2013 Tentang Penerapan Standar Pelayanan Minimum Bidang Keluarga Berencana dan Keluarga Sejahtera di Lingkungan Pemerintah Kabupaten Karawang. 
GJGOPS

P-ISSN: 2614-2120, E-ISSN: 2614-2104

Peraturan Daerah Kabupaten Karawang Nomor 6 Tahun 2018 tentang Penyelenggaraan Pembangunan Ketahanan Keluarga

Udang-Undang Nomor 133 Tahun 2013 Tentang Ketenagakerjaan

Undang-Undang Nomor 52 Tahun 2009 Tentang Perkembangan Kependudukan dan Pengembangan Keluarga. 